\title{
Tolerability of a new amino acid-based formula for children with IgE-mediated cow's milk allergy
}

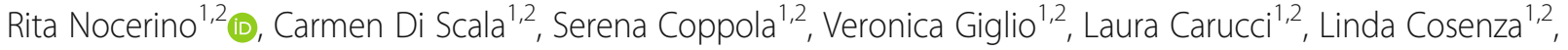 \\ Luana Voto ${ }^{1}$, Anna Maria lannicelli ${ }^{1}$, Anna Luzzetti ${ }^{1}$ and Roberto Berni Canani ${ }^{1,2,3,4^{*}}$
}

\begin{abstract}
Background: Amino acid-based formula (AAF) is a relevant dietary strategy for paediatric patients affected by cow's milk allergy (CMA). The present study was designed to evaluate the hypoallergenicity of a new AAF in children with immunoglobulin (Ig)E-mediated CMA.

Methods: According to the criteria provided by the American Academy of Pediatrics Subcommittee on Nutrition and Allergic Diseases, we designed a prospective trial in CMA children (aged 1-36 months) aimed to demonstrate the hypoallergenicity of the new AAF in $90 \%$ of subjects with 95\% confidence during the double-blind, placebocontrolled challenge (DBPCFC). A skin prick test (SPT) with the new AAF was also performed.
\end{abstract}

Results: Twenty-nine children [all Caucasian, 55.2\% male, mean age ( \pm SD) $16.9 \pm 5.7$ months] were enrolled. The SPT and the DBPCFC with the new AAF were negative in all study subjects.

Conclusions: The study results support the hypoallergenicity of the new AAF. This formula could be considered an additional dietary option for non-breastfed children affected by CMA.

Trial registration: The trial was registered in the ClinicalTrials.gov Protocol Registration System (ID number: NCT03909113).

Keywords: Infant formula, Hypoallergenic formula, Food allergy, Diet therapy

\section{Introduction}

With a 2.0 to $7.5 \%$ global prevalence, cow's milk allergy (CMA) is the most widespread food allergy (FA) in the paediatric age [1-7]. The current standard of care for CMA is based on the strict dietary avoidance of cow's milk protein-containing foods. For CMA infants, when breast milk is unavailable, the only remaining option is the use of a substitute formula, which is highly

\footnotetext{
*Correspondence: berni@unina.it

'Department of Translational Medical Science, University of Naples Federico II, Naples, Italy

${ }^{2}$ ImmunoNutritionLab at CEINGE Advanced Biotechnologies, University of Naples Federico II, Naples, Italy

Full list of author information is available at the end of the article
}

controlled for nutritional content and tolerance in these particular patients [8-15].

Amino acid-based formula (AAF) has been proposed for paediatric patients with severe CMA, multiple food allergies, eosinophilic esophagitis, food protein-induced enterocolitis syndrome, and severe eczema, or when the extensively hydrolyzed formula is not tolerated [16-20].

The American Academy of Pediatrics (AAP) Subcommittee on Nutrition and Allergic Diseases established criteria to determine the hypoallergenicity of any formula intended for children with CMA by demonstrating tolerance in $90 \%$ of children with CMA with a $95 \%$ confidence interval [22]. The present study was designed to evaluate the hypoallergenicity of a new AAF in children with confirmed immunoglobulin (Ig)E-mediated CMA. 


\section{Methods}

\section{Study design and study population}

This prospective trial was conducted from March 2019 to March 2020 on patients aged 1-36 months with sure diagnosis of IgE-mediated CMA consecutively observed at tertiary centre for paediatric allergy.

The CMA diagnosis was confirmed in all subjects by the results of double-blind, placebo-controlled food challenge (DBPCFC) performed in the last 12 weeks. We excluded subjects aged < 1 month and $>36$ months, breastfed infants, children with other food allergies, other allergic diseases, evidence of non-IgE-mediated CMA, eosinophilic disorders of the gastrointestinal tract, chronic systemic diseases, congenital cardiac defects, active tuberculosis, autoimmune diseases, immunodeficiency, chronic inflammatory bowel diseases, celiac disease, cystic fibrosis, metabolic diseases, malignancy, chronic pulmonary diseases, malformations of the gastrointestinal and/or respiratory tract, use of systemic antibiotics or anti-mycotic drugs during 4 weeks before study entry, presence of CMA-related symptoms in the previous 2 weeks, investigator's uncertainty about the willingness or ability of the subject to comply with the protocol requirements, and participation in any other studies involving investigational or marketed products concomitantly or within 2 weeks prior to entry into the study.

\section{Ethics}

The study protocol, the subject information sheet, the informed consent form, and the clinical chart were reviewed and approved by the Ethics Committee of the University of Naples Federico II. The study was conducted in accordance with the Helsinki Declaration (Fortaleza revision 2013), the Good Clinical Practice Standards (CPMP/ICH/135/95), and the current Decree-Law 196/2003 regarding personal data and all the requirements set out in the European regulations on this subject. The study was registered in the ClinicalTrials.gov Protocol Registration System with the ID number NCT03909113.

\section{Data collection}

At baseline, after obtaining informed consent from the parents/tutors of each subject, the clinical status of the patients was carefully assessed by a multidisciplinary team composed of paediatricians, paediatric allergists, paediatric nurses, and dietitians to exclude those with concomitant comorbidities. Infectious diseases or other conditions were ruled out by means of a complete physical examination, including vital signs, neurological status, body growth pattern, nutritional status, hydration, skin evaluation, otoscopy, evaluation of oral cavity, respiratory/abdomen/lymph node examination. At enrolment, anamnestic, demographic, anthropometric, and clinical data (including data related to CMA), as well as information on sociodemographic factors, were obtained from the parents of each child, collected in a specific clinical chart, and entered into the study database.

Then, a skin prick test (SPT) with the new AAF was performed. Briefly, the skin prick test was performed with the new AAF reconstituted according to the manufacturer's instructions. The new AAF was applied to the patient's volar forearm. Skin prick tests were performed using a 1-mm single peak lancet (ALK, Copenhagen, Denmark) with histamine dihydrochloride $(10 \mathrm{mg} / \mathrm{ml})$ and an isotonic saline solution $(\mathrm{NaCl} 0.9 \%)$ as positive and negative controls, respectively. Reactions were recorded on the basis of the largest diameter (in millimetres) of the wheal-and-flare reaction at $15 \mathrm{~min}$. The SPT result was considered "positive" if the wheal was 3 $\mathrm{mm}$ or larger, without reaction to the negative control.

Subsequently, the patients underwent the DBPCFC with the new AAF or the placebo formula (namely, the formula previously given to the child as part of the child's successful elimination diet before study inclusion) introduced in a random order, as previously described [23].

We created a computer-generated randomization list of participant numbers indicating the order in which each study formula was used in the oral food challenge (OFC). Randomization and preparation of the challenges were performed by an independent dietician not directly involved in the study and in the patient's care. In addition, bottles were covered by a paper sheet so that they were not distinguishable. The investigator, the nursing staff, and the family were therefore not informed of what formula the child was being fed.

Before each OFC day, the investigator ensured that the child did not present any clinical abnormalities and had stopped all medications, including anti-histamines, that could have interfered with the administration of the OFC. Subjects were eating nothing for $1 \mathrm{~h}$ with allowance for light meals $2 \mathrm{~h}$ prior to each session of OFC.

Briefly, every $20 \mathrm{~min}$, successive doses $(0.5,1,3,10,30$, 50 and $100 \mathrm{~mL}$ ) were administered in a blinded manner under medical supervision. The infants were observed for $2 \mathrm{~h}$ after the final dose and then discharged. In the case of a positive OFC, at any testing dose, the patient was treated as deemed necessary by the investigator and remained under observation until symptom resolution.

If patients did not show any symptoms within the first $24 \mathrm{~h}$, to assess long-term tolerance and reveal any falsenegative results to the challenges, parents administered one single top dose (about $200 \mathrm{ml}$ ) of the tested formula (new AAF or placebo) to the patients every day at home for 7 days (7-day home feeding period), and parents were instructed not to introduce any new foods. In addition, an emergency treatment plan and prescriptions for emergency medications were provided to the parents. If any symptoms occurred during this period, the subjects 
Table 1 Composition of the study formula

\begin{tabular}{|c|c|c|c|}
\hline & & $100 \mathrm{~g}$ & $\begin{array}{l}100 \mathrm{~mL} \\
\text { at } 13 \% \mathrm{w} / \mathrm{v}\end{array}$ \\
\hline \multirow[t]{2}{*}{ Calories } & $\mathrm{kJ}$ & 1974 & 256 \\
\hline & kcal & 471 & 61 \\
\hline Total fat & g & 21.0 & 2.7 \\
\hline Saturated fat & $g$ & 7.8 & 1.0 \\
\hline Monounsaturated fat & $g$ & 9.8 & 1.3 \\
\hline Polyunsaturated fat & $g$ & 3.0 & 0.4 \\
\hline Total carbohydrate & g & 58.2 & 7.6 \\
\hline Sugars & $g$ & 0.0 & 0.0 \\
\hline Protein & g & 12.2 & 1.6 \\
\hline Salt & g & 0.41 & 0.05 \\
\hline \multicolumn{4}{|l|}{ Minerals } \\
\hline Sodium & $\mathrm{mg}$ & 165 & 21 \\
\hline Potassium & $\mathrm{mg}$ & 570 & 74.1 \\
\hline Chloride & $\mathrm{mg}$ & 300 & 39 \\
\hline Calcium & $\mathrm{mg}$ & 460 & 59.8 \\
\hline Phosphorus & $\mathrm{mg}$ & 295 & 38.4 \\
\hline Magnesium & $\mathrm{mg}$ & 42 & 5.46 \\
\hline Iron & $\mathrm{mg}$ & 6.9 & 0.90 \\
\hline Zinc & $\mathrm{mg}$ & 7.1 & 0.92 \\
\hline Copper & $g$ & 420 & 55 \\
\hline lodine & $g$ & 99 & 12.9 \\
\hline Manganese & $\mathrm{mg}$ & 0.41 & 0.05 \\
\hline Fluorine & $\mathrm{mg}$ & 0.3 & 0.04 \\
\hline Molybdenum & $g$ & 14.5 & 1.9 \\
\hline Chromium & $g$ & 14.5 & 1.9 \\
\hline Selenium & g & 9.0 & 1.2 \\
\hline \multicolumn{4}{|l|}{ Vitamins } \\
\hline Vitamin A & $\mu \mathrm{g} R$ & 550 & 71.5 \\
\hline Vitamin D & $\mu g$ & 8.0 & 1.0 \\
\hline Thiamin & $\mathrm{mg}$ & 0.5 & 0.065 \\
\hline Riboflavin & $\mathrm{mg}$ & 0.8 & 0.10 \\
\hline Niacin & $\mathrm{mg}$ & 5.4 & 0.70 \\
\hline Vitamin B6 & $\mathrm{mg}$ & 0.7 & 0.09 \\
\hline Pantothenic Acid & $\mathrm{mg}$ & 3.0 & 0.39 \\
\hline Biotin & $\mu \mathrm{g}$ & 20 & 2.6 \\
\hline Folic Acid & $\mu \mathrm{g}$ & 75 & 9.75 \\
\hline Vitamin B12 & $\mu \mathrm{g}$ & 2.1 & 0.27 \\
\hline Vitamin C & $\mathrm{mg}$ & 63 & 8.2 \\
\hline Vitamin K & $\mu \mathrm{g}$ & 60 & 7.8 \\
\hline Vitamin $\mathrm{E}$ & $\mathrm{mg}$ & 10 & 1.3 \\
\hline \multicolumn{4}{|l|}{ Other nutrition facts } \\
\hline Choline & $\mathrm{mg}$ & 98 & 13 \\
\hline Inositol & $\mathrm{mg}$ & 20 & 2.6 \\
\hline
\end{tabular}

Table 1 Composition of the study formula (Continued)

\begin{tabular}{|c|c|c|c|}
\hline & & $100 \mathrm{~g}$ & $\begin{array}{l}100 \mathrm{~mL} \\
\text { at } 13 \% \mathrm{w} / \mathrm{v}\end{array}$ \\
\hline L-carnitine & $\mathrm{mg}$ & 17.9 & 2.3 \\
\hline Taurin & $\mathrm{mg}$ & 40 & 5.2 \\
\hline Linoleic Acid (LA) & $\mathrm{mg}$ & 2900 & 377 \\
\hline a-linolenic Acid (ALA) & $\mathrm{mg}$ & 294 & 38 \\
\hline Maltodextrins & $g$ & 42.3 & 5.5 \\
\hline \multicolumn{4}{|l|}{ Nucleotides } \\
\hline Adenosine-5'-monophosphate & $\mathrm{mg}$ & 6.9 & 0.9 \\
\hline Cytidine-5'-monophosphate & $\mathrm{mg}$ & 3.8 & 0.5 \\
\hline Guanosine-5'-monophosphate & $\mathrm{mg}$ & 1.3 & 0.2 \\
\hline Inosine $-5^{\prime}$-monophosphate & $\mathrm{mg}$ & 2.5 & 0.3 \\
\hline Uridine - 5'-monophosphate & $\mathrm{mg}$ & 4.5 & 0.6 \\
\hline Osmolarity & mOsmol/l & 216 & \\
\hline
\end{tabular}

The composition of the new amino acid based formula was fully in line with the composition of other commercially available amino acid based formulas and with the actual recommendation for energy requirement provided by European Food Safety Authority (reference \#27)

returned to the outpatient clinic on the same day. During the 7-d home feeding period, parents were invited to record daily the following: the total amount of formula ingested by the subject; the types of foods eaten; the presence and severity of vomiting, diarrhoea, rash, runny nose, wheezing, or any other symptoms (rated as mild, moderate, or excessive); the number of bowel movements and stool colour, consistency and odour; any adverse or serious adverse events; and the formula acceptability by their child, from very unsatisfied to very satisfied. After a 7-day home feeding period of the new AAF or placebo administration, the patients were examined, and the parents were interviewed at the centre. To rule out a false-negative challenge result, parents contacted the centre if any symptoms occurred in the following 7 days after the OFC procedures. The challenge was considered negative if the patient tolerated the entire challenge, including the observation period.

All objective and subjective symptoms were assessed simultaneously by experienced paediatric allergists and were registered using a standardized symptom score [23, 24] (Supplementary Table 1).

The new AAF was provided by the study sponsor and was reconstituted according to the manufacturer's instructions. The composition of the new AAF is described in Table 1.

All study procedures and assessments were performed as shown in Fig. 1.

\section{Study outcome}

The primary study outcome was the evaluation of the hypoallergenicity of the new AAF paediatric patients with IgE-mediated CMA. 


\begin{tabular}{|c|c|c|c|c|c|c|}
\hline $\begin{array}{c}\text { Visit } 1 \\
\text { Day } 0\end{array}$ & $\begin{array}{c}\text { Visit } 2 \\
\text { Day } 1\end{array}$ & $\begin{array}{l}\text { Visit } 3 \\
\text { Day } 3\end{array}$ & $\begin{array}{l}\text { 7-day home } \\
\text { feeding period }\end{array}$ & $\begin{array}{l}\text { Visit } 4 \\
\text { Day } 10\end{array}$ & $\begin{array}{l}\text { Visit } 4 \\
\text { Day } 17\end{array}$ & \\
\hline $\begin{array}{l}\text { Assessment of } \\
\text { eligibility }\end{array}$ & Evaluation & \multicolumn{3}{|c|}{2 d-DBPCFC } & Re-evaluation & Data analysis \\
\hline $\begin{array}{c}\text { Multidisciplinary team } \\
\text { (pediatricians, paediatricians } \\
\text { experienced in paediatric } \\
\text { allergy, pediatric nurses, } \\
\text { dietitians) }\end{array}$ & $\begin{array}{c}\text { Paediatrician } \\
\text { experienced in } \\
\text { paediatric allergy }\end{array}$ & \multicolumn{3}{|c|}{$\begin{array}{c}\text { Multidisciplinary team } \\
\text { (paediatricians experienced in } \\
\text { paediatric allergy, pediatric nurses, } \\
\text { dietitians) }\end{array}$} & $\begin{array}{c}\text { Paediatrician } \\
\text { experienced in } \\
\text { paediatric allergy }\end{array}$ & Biostatistician \\
\hline $\begin{array}{l}\text { - Anamnestic and clinical } \\
\text { evaluation } \\
\text { - Inclusion/exclusion } \\
\text { criteria } \\
\text { - Demographic data } \\
\text { collection } \\
\text { - Informed consent }\end{array}$ & $\begin{array}{l}\text { - Full clinical } \\
\text { evaluation } \\
\text { - Skin prick test to } \\
\text { new AAF }\end{array}$ & \multicolumn{3}{|c|}{$\begin{array}{l}\text { - Oral food challenges } \\
\text { • Clinical diary } \\
\text { - Full clinical evaluation }\end{array}$} & $\begin{array}{l}\text { - Clinical diary } \\
\text { - Full clinical } \\
\text { evaluation }\end{array}$ & $\begin{array}{l}\text { - Data } \\
\text { management } \\
\text { - Statistical } \\
\text { analysis }\end{array}$ \\
\hline \multicolumn{7}{|c|}{$\begin{array}{l}\text { Additional visit(s) were performed when necessary. } \\
\text { AAF: amino acid based formula; DBPCFC: double-blind placebo-controlled food challenge }\end{array}$} \\
\hline Fig. 1 The design of the study & & & & & & \\
\hline
\end{tabular}

\section{Sample size}

The sample size was calculated according to the AAP guidelines for clinical testing of hypoallergenic formulas [22]. In a study with a binomial outcome (reaction versus no reaction), the sample size can be determined by calculating a binomial confidence interval $(\mathrm{CI})$ for $\mathrm{p}$, the probability of having a reaction. The number of subjects needed to project with
95\% confidence (one-sided interval) that less than $10 \%$ of infants will react to the product is 29 consecutive subjects if no clinical reactions are observed. These sample size estimates were derived based on binomial distribution techniques using Wald's method for deriving confidence intervals for single proportions (software used: R Version 3.1.0-The R foundation for statistical computing).

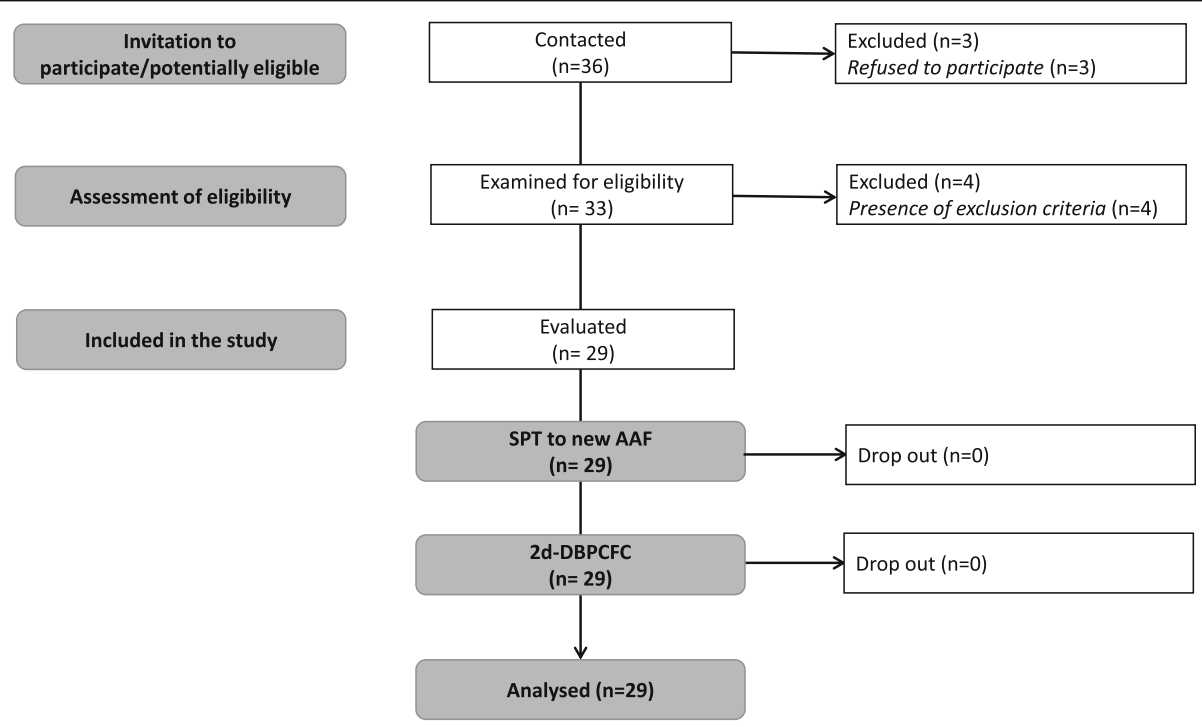

SPT: skin prick test; AAF: amino acid based formula; DBPCFC: double-blind placebo-controlled food challenge

Fig. 2 Flow of the children through the study 


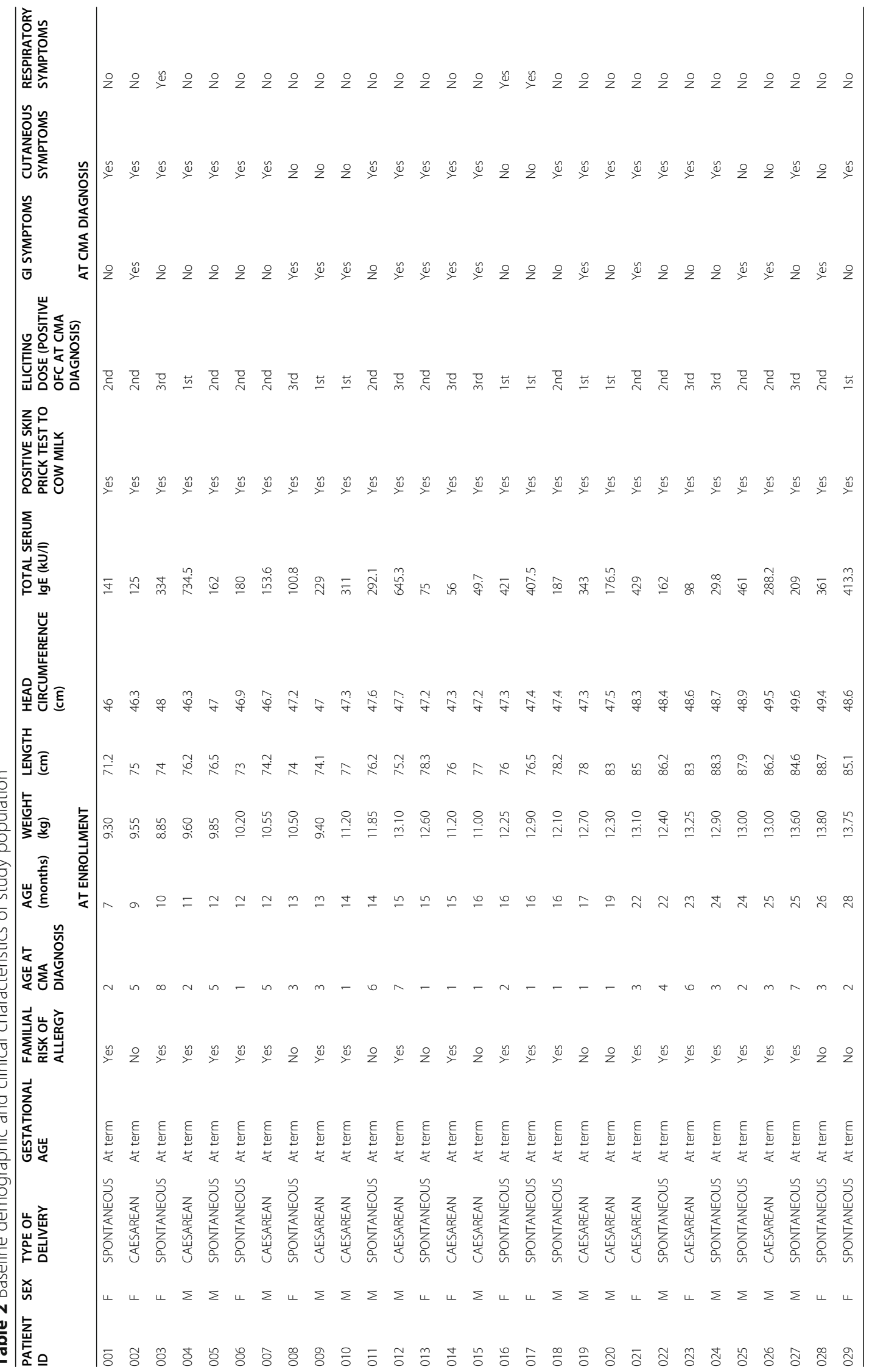




\section{Statistical analysis}

The Kolmogorov-Smirnov test was used to determine whether variables were normally distributed. Descriptive statistics were reported as the means and standard deviations for continuous variables, and discrete variables were reported as the number and proportion of subjects with the characteristic of interest. All data were collected in a dedicated database and analysed by a statistician blinded to patient group assignment using SPSS for Windows (SPSS Inc., version 23.0, Chicago, IL).

\section{Results}

The flow of the subjects during the study is reported in Fig. 2.

A total of 36 consecutively potentially eligible paediatric patients were contacted and invited to participate in the study. Three subjects refused to participate; thus, 33 patients were examined for eligibility, and 4 were excluded because of the presence of exclusion criteria, leaving a total of 29 children included. All study subjects [all Caucasian, $55.2 \%$ male, mean age $( \pm S D)$ at enrolment $16.9 \pm 5.7$ months] were from families of middle socioeconomic status and lived in urban areas. All subjects were weaned at enrolment and were receiving a cow's milk protein-free diet according to age-related energy requirements. The formulas that the subjects were receiving at study entry were extensively hydrolyzed casein formula containing the probiotic Lactobacillus rhamnosus GG (37.9\%), hydrolyzed rice formula (20.7\%), extensively hydrolyzed whey formula $(17.2 \%)$, soy formula (10.3\%), or AAF (13.8\%).

The main demographic and clinical features of the study subjects at enrolment are depicted in Table 2. The SPT with the new AAF was negative in all study subjects. Similarly, all children passed the DBPCFC with the new AAF.

The new study formula was well accepted by the children, as confirmed by daily parental records and the very high adherence rate of subjects during the OFC and the 7 -day open phase.

\section{Discussion}

This is the first study investigating the tolerance to this new AAF in paediatric patients with challenge-proven IgE-mediated CMA. The study provided $95 \%$ confidence that more than $90 \%$ of subjects with CMA tolerate the new AAF, thus demonstrating the hypoallergenicity of this formula.

The hypoallergenicity of the new AAF was further confirmed by the SPT result, which was negative in all study subjects.

The amino acid-based formula is considered the only completely non-allergenic formula. It can be the best effective dietary option in patients who do not respond to extensively hydrolyzed formulas, in patients with anaphylaxis or with severe forms of CMA [13, 25-27].

This study presents several strengths. First, it was performed on a well-characterized population of children with previous challenge-proven IgE-mediated CMA followed by specialists at a tertiary paediatric allergy centre. Second, the methodology adopted in this study was rigorous. Nonetheless, this study has limitations. Our data cannot be generalized to children with conditions that were reasons for exclusion from the study. Another limitation of our study is the lack of results of the longer evaluation of body growth of the enrolled patients, but the composition of the new AAF was fully in line with the composition of other commercially available AAFs and with the actual recommendation for energy requirement provided by the European Food Safety Authority [28]. Thus, we can assume that this new AAF could provide normal body growth for paediatric patients affected by CMA. To better assess this aspect, future studies are advocated. Finally, as in other studies conducted on AAFs, further studies are required to investigate the long-term effects of this dietary treatment on the time of immune tolerance acquisition in children with CMA.

In conclusion, the new AAF meets the AAP criteria for hypoallergenicity, is well tolerated in short-term use and constitutes an additional safe option among the various formulas already available for the dietary management of non-breastfed children with CMA.

\section{Abbreviations \\ CMA: Cow's milk allergy; CMP: Cow milk protein; IgE: Immunoglobulin E; AAF: Amino acid-based formula; AAP: American Academy of Paediatrics; DBPCFC: Double-blind, placebo-controlled challenge; OFC: Oral food challenge; SPT: Skin prick test; SD: Standard deviation; Cl: Confidence interval}

\section{Supplementary Information}

The online version contains supplementary material available at https://doi. org/10.1186/s13052-021-01096-3.

Additional file 1: Supplementary Table 1. Pre-specified scale of allergic symptoms used to assess reactions during the double-blind placebocontrolled food challenge.

\section{Acknowledgements}

Not applicable.

\section{Authors' contributions}

$\mathrm{RN}$ and RBC conceived the study, participated in its design and coordination and wrote the manuscript. RN, CDS, SC, LC, LC, VG, AMI, AL, and LV cared for the patients. RN performed the statistical analysis. All authors read and approved the final manuscript.

\section{Authors' information}

Not applicable

\section{Funding}

This study was supported in part by an unrestricted grant from Humana Italia S.p.A devoted to the Department of Translational Medical Science of the University of Naples "Federico II". Humana Italia S.p.A. had no influence 
on (1) the study design (2); the collection, analysis, and interpretation of the data (3); the writing of the manuscript; or (4) the decision to submit the manuscript for publication.

\section{Availability of data and materials}

The datasets used and/or analysed during the current study are available from the corresponding author on reasonable request.

\section{Declarations}

\section{Ethics approval and consent to participate}

The study protocol, the subject information sheet, the informed consent form, and the clinical chart were reviewed and approved by the Ethics Committee of the University of Naples Federico II. Institution. The study was conducted in accordance with the Helsinki Declaration (Fortaleza revision 2013), the Good Clinical Practice Standards (CPMP//CH/135/95), and the current Decree-Law 196/2003 regarding personal data and all the requirements set out in the European regulations on this subject. The study is a part of a project and was registered in the ClinicalTrials.gov Protocol Registration System with the ID number NCT03909113.

\section{Consent for publication}

Not applicable.

\section{Competing interests}

The authors have no conflicts of interest that are directly relevant to the content of this paper, which remains their sole responsibility.

\section{Author details}

'Department of Translational Medical Science, University of Naples Federico II, Naples, Italy. ${ }^{2}$ ImmunoNutritionLab at CEINGE Advanced Biotechnologies, University of Naples Federico II, Naples, Italy. ${ }^{3}$ European Laboratory for the Investigation of Food-Induced Diseases, University of Naples, Federico II, Naples, Italy. ${ }^{4}$ Task Force on Microbiome Studies, University of Naples Federico II, Via S. Pansini 5, 80131 Naples, Italy.

Received: 16 July 2020 Accepted: 31 May 2021

Published online: 03 July 2021

\section{References}

1. Fiocchi A, Dahdah L, Albarini M, Martelli A. Cow's milk allergy in children and adults. Chem Immunol Allergy. 2015;101:114-23. https://doi.org/10.11 59/000375415

2. Sicherer SH. Epidemiology of food allergy. J Allergy Clin Immunol. 2011; 127(3):594-602. https://doi.org/10.1016/j.jaci.2010.11.044.

3. Schoemaker AA, Sprikkelman AB, Grimshaw KE, Roberts G, Grabenhenrich L, Rosenfeld $L$, et al. Incidence and natural history of challenge-proven cow's milk allergy in European children--EuroPrevall birth cohort. Allergy. 2015; 70(8):963-72. https://doi.org/10.1111/all.12630.

4. Skripak JM, Matsui EC, Mudd K, Wood RA. The natural history of IgEmediated cow's milk allergy. J Allergy ClinImmunol. 2007;120(5):1172-7. https://doi.org/10.1016/j.jaci.2007.08.023.

5. Rona RJ, Keil T, Summers C, Gislason D, Zuidmeer L, Sodergren E, et al. The prevalence of food allergy: a meta-analysis. J Allergy ClinImmunol. 2007; 120(3):638-46. https://doi.org/10.1016/j.jaci.2007.05.026.

6. Koletzko S, Niggemann B, Arato A, Dias JA, Heuschkel R, Husby S, et al. Diagnostic approach and management of cow's-milk protein allergy in infants and children: ESPGHAN GI Committee practical guidelines. J PediatrGastroenterolNutr. 2012;55:221-9.

7. Savage J, Sicherer S, Wood R. The natural history of food allergy. J Allergy ClinImmunolPract. 2016:4:196-203.

8. Vandenplas Y, Marchand J, Meyns L. Symptoms, diagnosis, and treatment of Cow's Milk allergy. CurrPediatr Rev. 2015;11:293-7.

9. Ludman S, Shah N, Fox AT. Managing cows' milk allergy in children. BMJ. 2013;347(sep16 1):f5424. https://doi.org/10.1136/bmj.f5424.

10. Fiocchi A, Brozek J, Schünemann H, Bahna SL, von Berg A, Beyer K, et al. World Allergy Organization (WAO) Diagnosis and Rationale for Action against Cow's Milk Allergy (DRACMA) Guidelines. Pediatr Allergy Immunol. 2010;21(Suppl 21):1-125.
11. Host A, Halken S. Hypoallergenic formulas-when, to whom and how long: after more than 15 years we know the right indication! Allergy. 2004; 59(Suppl 78):45-52. https://doi.org/10.1111/j.1398-9995.2004.00574.x.

12. Hays T, Wood RA. A systematic review of the role of hydrolyzed infant formulas in allergy prevention. Arch Pediatr Adolesc Med. 2005;159(9):810-6. https://doi.org/10.1001/archpedi.159.9.810.

13. Koletzko S, Niggemann B, Arato A, Dias JA, Heuschkel R, Husby S, et al. European Society of Pediatric Gastroenterology, Hepatology, and NutritionDiagnostic approach and management of cow's-milk protein allergy in infants and children: ESPGHAN Gl committee practical guidelines. J Pediatr Gastroenterol Nutr. 2012; 55(2):221-9. https://doi.org/10.1097/MPG.0b013e31825c9482.

14. D'Auria E, Abrahams M, Zuccotti GV, Venter C. Personalized nutrition approach in food allergy: is it prime time yet? Nutrients. 2019;11(2). https:// doi.org/10.3390/nu11020359.

15. D'Auria E, Mameli C, Piras C, Cococcioni L, Urbani A, Zuccotti GV, et al. Precision medicine in cow's milk allergy: proteomics perspectives from allergens to patients. J Proteome. 2018;188:173-80. https://doi.org/10.1016/j. jprot.2018.01.018.

16. Venter C, Brown T, Meyer R, Walsh J, Shah N, Nowak-Wegrzyn A, et al. Better recognition, diagnosis and management of non-lgE-mediated cow's milk allergy in infancy: iMAP — an International Interpretation of the MAP (Milk Allergy in Primary Care) guideline. Clin Transl Allergy. 2017;7(1):26. https:// doi.org/10.1186/s13601-017-0162-y.

17. Luyt D, Ball H, Makwana N, Green MR, Bravin K, Nasser SM, et al. BSACl guideline for the diagnosis and management of cow's milk allergy. Clin Exp Allergy. 2014;44(5):642-72. https://doi.org/10.1111/cea.12302.

18. Chehade M, Aceves SS, Furuta GT, Fleischer DM. Food allergy and eosinophilic esophagitis: what do we do? J Allergy Clin Immunol Pract. 2015;3(1):25-32. https://doi.org/10.1016/j.jaip.2014.11.009.

19. Nowak-Węgrzyn A, Chehade M, Groetch ME, Spergel JM, Wood RA, Allen K, et al. International consensus guidelines for the diagnosis and management of food protein-induced enterocolitis syndrome: workgroup report of the adverse reactions to foods committee, American academy of allergy, asthma, and immunology. J Allergy Clin Immunol. 2017;139(4):1111-26. https://doi.org/10.1016/j.jaci.2016.12.966.

20. Fiocchi A, Bouygue GR, Martelli A, Terracciano L, Sarratud T. Dietary treatment of childhood atopic eczema/dermatitis syndrome (AEDS). Allergy. 2004;59(suppl 78):78-85.

21. Meyer R, Groetch M, Venter C. When should infants with cow's milk protein allergy use an amino acid formula? A practical guide. J Allergy Clin Immunol Pract. 2018:6:383-399.

22. American Academy of Pediatrics. Committee on Nutrition. Hypoallergenic infant formulas. Pediatrics. 2000;106(2):346-9. https://doi.org/10.1542/peds.106.2.346.

23. Sampson HA, Gerth van Wijk R, Bindslev-Jensen C, Sicherer S, Teuber SS, Burks AW, et al. Standardizing double-blind, placebo controlled oral food challenges: American Academy of allergy, asthma \& immunology-European academy of allergy and clinical immunology PRACTALL consensus report. J Allergy Clin Immunol. 2012;130(6):1260-74. https://doi.org/10.1016/j.jaci.2 012.10.017.

24. Nowak-Wegrzyn A, Assa'ad AH, Bahna SL, Bock SA, Sicherer SH, Teuber SS, et al. Work group report: oral food challenge testing. J Allergy Clin Immunol. 2009;123(6):S365-83. https://doi.org/10.1016/j.jaci.2009.03.042.

25. Hill DJ, Murch SH, Rafferty K, Wallis P, Green CJ. The efficacy of amino acidbased formulas in relieving the symptoms of cow's milk allergy: a systematic review. Clin Exp Allergy. 2007;37(6):808-22. https://doi.org/1 0.1111/j.1365-2222.2007.02724.x.

26. Niggemann B, von Berg A, Bollrath C, Berdel D, Schauer U, Rieger C, et al. Safety and efficacy of a new extensively hydrolyzed formula for infants with cow's milk protein allergy. Pediatr Allergy Immunol. 2008;19(4):348-54. https://doi.org/10.1111/j.1399-3038.2007.00653.x.

27. Muraro A, Werfel T, Hoffmann-Sommergruber K, Roberts G, Beyer K, Bindslev-Jensen $C$, et al. EAACl food allergy and anaphylaxis guidelines group. EAACl food allergy and anaphylaxis guidelines: diagnosis and management of food allergy. Allergy. 2014;69(8):1008-25. https://doi.org/1 0.1111 /all.12429.

28. EFSA Panel on Dietetic Products, Nutrition and Allergies (NDA). Scientific Opinion on Dietary Reference Values for energy. EFSA J. 2013;11(1):3005.

\section{Publisher's Note}

Springer Nature remains neutral with regard to jurisdictional claims in published maps and institutional affiliations. 